\title{
New records and an updated map of distribution of Micrurus camilae Renjifo \& Lundberg, 2003 (Elapidae) for Colombia
}

\author{
Elson Meneses-Pelayo ${ }^{1}$, Diana Caballero ${ }^{2}$ \\ 1 Grupo de Estudios en Anfibios y Reptiles de Santander (GEARS), Universidad Industrial de Santander, Carrera 27, Calle 9, Bucaramanga, \\ Santander, Colombia. 2 ISAGEN S.A. ESP, Carrera 30 \# 10C-280 transversal inferior, El Poblado, Medellín, Colombia. \\ Corresponding author: Elson Meneses-Pelayo, bioelsonp@gmail.com
}

\begin{abstract}
Camila's Coral Snake, Micrurus camilae Renjifo \& Lundberg, 2003, is known only by 3 collected specimens. In this work, we report for the first time the presence of M. camilae in the middle Magdalena Valley, and we add data about color variation in the species. The new record extends the distributional range of M. camilae by nearly $200 \mathrm{~km}$ in a straight line from Vereda El Rayo, Tarazá, Antioquia, which is the nearest point previously reported.
\end{abstract}

\section{Keywords}

Chocó-Magdalena province, coral snake, Neotropics, range extension

Academic editor: Raul F.D. Sales | Received 4 February 2019 | Accepted 26 May 2019 | Published 7 June 2019

Citation: Meneses-Pelayo E, Caballero D (2019) New records and an updated map of distribution of Micrurus camilae Renjifo \& Lundberg, 2003 (Elapidae) for Colombia. Check List 5 (3): 465-469. https://doi.org/10.15560/15.3.465

\section{Introduction}

The term New World coral snakes is used to refer to the American snakes of the genera Micruroides Schmidt, 1928 and Micrurus Wagler, 1824. These genera form the subfamily Elapinae (sensu Slowinski et al. 2001) based on molecular and morphological characteristics. Of these 2 genera, Micrurus currently comprises 86 species (Uetz and Hošek 2019) inhabiting lowland rainforests and deserts to highland cloud forests, between 0 and $3000 \mathrm{~m}$ above sea level, from the southern United States through Mexico, Central America, and most of South America to central Argentina (Campbell and Lamar 2004, Silva Jr et al. 2016, Guedes et al. 2018). In Colombia, there are records of 30 species (Uetz and Hošek 2019, Guedes et al. 2018), of which very few aspects are known about their biology, systematics, and distribution. In this work, we present an extension of distribution, and new morphological and ecological data for Micrurus camilae Renjifo \& Lundberg, 2003 which was until now, known from only 2 specimens of the type series (Renjifo and Lunbberg 2003) and an additional specimen recorded in Tarazá, Antioquia (Alzate 2014).

\section{Methods}

Aiming to obtain new records of M. camilae in Colombia, we examined the collections of ICN (Instituto de Ciencias Naturales, Universidad Nacional de Colombia) and UIS (Colección de Herpetología, Universidad Industrial de Santander, Bucaramanga, Santander). Literature 
Table 1. Full list of the occurrence localities of Micrurus camilae in Colombia, based on literature, museum data, and photographic records.

\begin{tabular}{lllllcc}
\hline Specimen & Department & Municipality,Locality & Latitude & Longitude & Elevation (m) & Source \\
\hline ICN-8506 & Córdoba & Tierra Alta, Hidroeléctrica de Urrá I & 08.017611 & -076.185583 & 90 & Renjifo and Lunbberg 2003 \\
ICN-8507 & Córdoba & Tierra Alta, Hidroeléctrica de Urrá I & 08.017611 & -076.185583 & 90 & Renjifo and Lunbberg 2003 \\
MHUA-R-14894 & Antioquia & Tarazá, Vda. El Rayo & 07.495638 & -075.372868 & 160 & Alzate 2014 \\
UIS-R-4164 & Santander & Barrancabermeja, La Lizama & 05.6419 & -077.0755 & 143 & MHN-UIS \\
UIS-R-4416 & Santander & Betulia, Vda. La Putana, El Cedral & 07.122778 & -073.455833 & 176 & MHN-UIS \\
Photo & Santander & Barrancabermeja, Vda. Planta Nueva & 06.994144 & -073.760125 & 88 & HSE \\
Photo & Antioquia & Apartadó, Vda. Salsipuedes & 07.859975 & -076.597900 & 60 & Carlos Bran \\
\hline
\end{tabular}

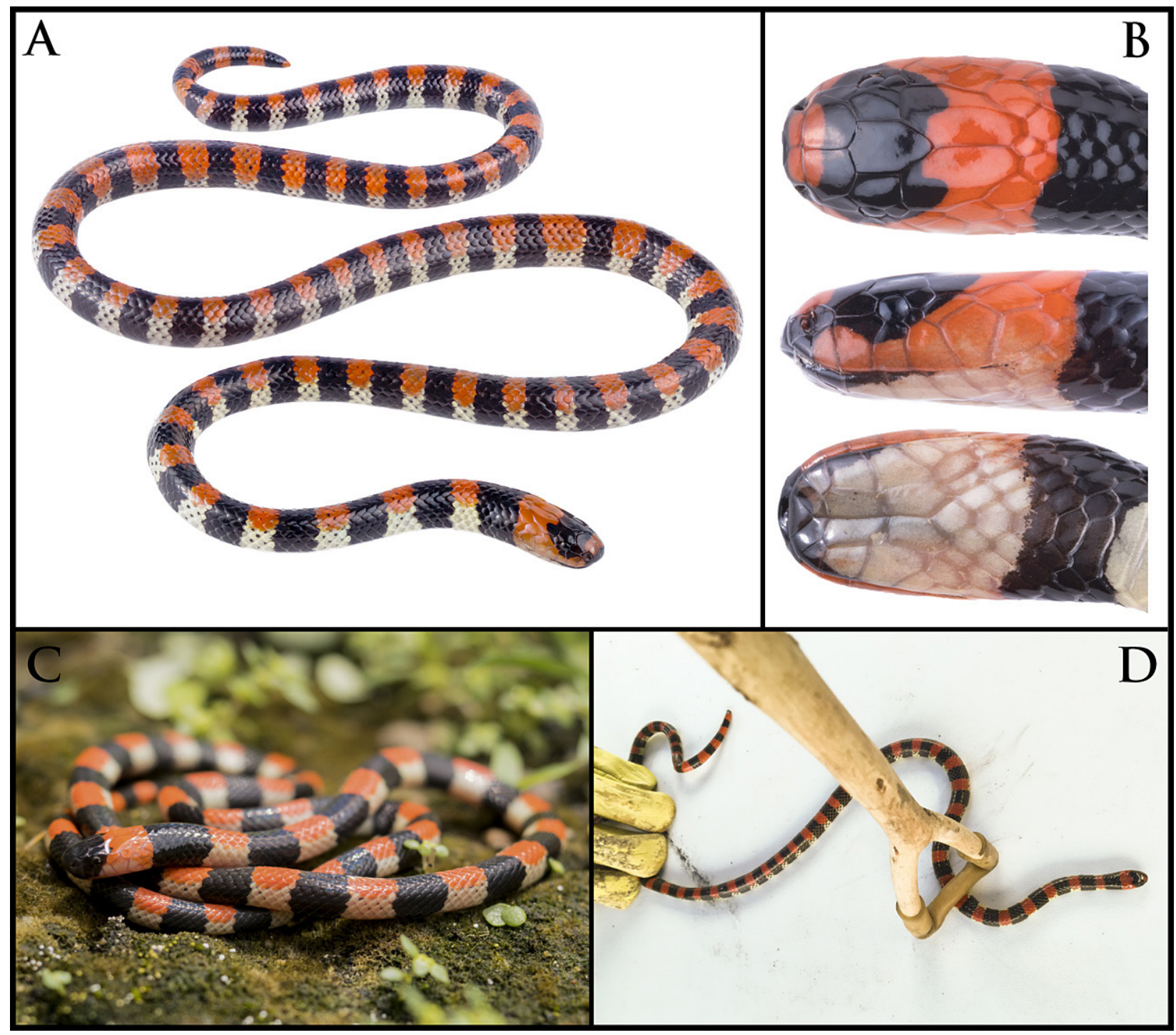

Figure 1. Micrurus camilae. A, B. juvenile female (UIS-R-4164) from La Lizama, Santander. C. Photographic record in Apartadó municipality, Antioquia. D. Protographic record in Barrancabermeja, Santander. Photos: A, B. Elson Meneses-Pelayo. C. Carlos Bran. D. Grupo manejo de fauna Health Safety and Environment Ltd.

records, museum databases, and photographic records with precise localities were also examined (Table 1). For each preserved specimen of $M$. camilae we recorded (1) the number of black rings, (2) the number of ventral scales, (3) the number of subcaudal scales, (4) the organization of the labial scales, and (5) the total length (Table 2). Species identification was based on literature, taxonomic keys, and with direct comparisons with the type series (Renjifo and Lundberg 2003; Alzate 2014).

\section{Results}

New records. Colombia: Santander, Barrancabermeja municipality: La Lizama $\left(05.6419^{\circ} \mathrm{N}, 077.0755^{\circ} \mathrm{W} ; 143\right.$ $\mathrm{m}$ alt.), 1 juvenile female, in an African palm crop, coll. by Rafael Mantilla, 19 June 2005, (UIS-R-4164, Figs 1A, B, 2A). Colombia: Santander, Betulia municipality: El Cedral, Vereda La Putana $\left(07.1228^{\circ} \mathrm{N}, 073.4558^{\circ} \mathrm{W} ; 176\right.$ $\mathrm{m}$ alt.), 1 adult male, in gardens of administrative cen- 
ter of ISAGEN, coll. by Diana Caballero, 5 April 2018 (UIS-4416, Fig. 2B). Colombia: Antioquia, Apartadó municipality: surrounding road of the city $\left(07.8600^{\circ}\right.$
$\mathrm{N}, 076.5979^{\circ} \mathrm{W} ; 60 \mathrm{~m}$ alt.), recorded on 17 July 2018 (Carlos Bran, photographic record, Fig. 1C). Colombia: Santander, Barrancabermeja municipality: Vereda Planta

Table 2. Morphological data of the specimens of Micrurus camilae examined in this work. Temporals account for anterior and posterior temporals respectively. For postoculars, a slash (/) is used when the counts from left/right sides are different. Values from examined specimens that expand the hitherto documented variation are in bold font.

\begin{tabular}{|c|c|c|c|c|c|}
\hline & \multicolumn{5}{|c|}{ Micrurus camilae } \\
\hline & \multicolumn{2}{|c|}{ Renjifo and Lunbberg (2003) } & \multirow{2}{*}{$\begin{array}{c}\text { Alzate (2014) } \\
\text { MHUA-R-14894 }\end{array}$} & \multicolumn{2}{|c|}{ This work } \\
\hline & ICN-8506 & ICN-8507 & & UIS-R-4164 & UIS-R-4416 \\
\hline Sex & Male & Male & Female & Female & male \\
\hline $\mathrm{TL}(\mathrm{mm})$ & 291.8 & 247 & - & 240 & 630 \\
\hline Dorsals & $15-15-15$ & $15-15-15$ & $15-15-15$ & $15-15-15$ & $15-15-15$ \\
\hline Preventrals & - & - & 4 & 4 & 4 \\
\hline Ventrals & 269 & - & 303 & 301 & 268 \\
\hline Subcaudals & 41 & - & 30 & 30 & 40 \\
\hline Supralabials & 7 & - & 7 & 7 & 7 \\
\hline Infralabials & 7 & - & 7 & 7 & 7 \\
\hline Temporals & $1+1$ & - & $1+1$ & $1+1$ & $1+1$ \\
\hline Postoculars & $2 / 2$ & - & $2 / 1$ & $2 / 2$ & $2 / 2$ \\
\hline $\begin{array}{l}\text { Black rings } \\
\text { Body-tail }\end{array}$ & $31-4$ & $36-4$ & $46-5$ & $58-5$ & 43-5 \\
\hline
\end{tabular}

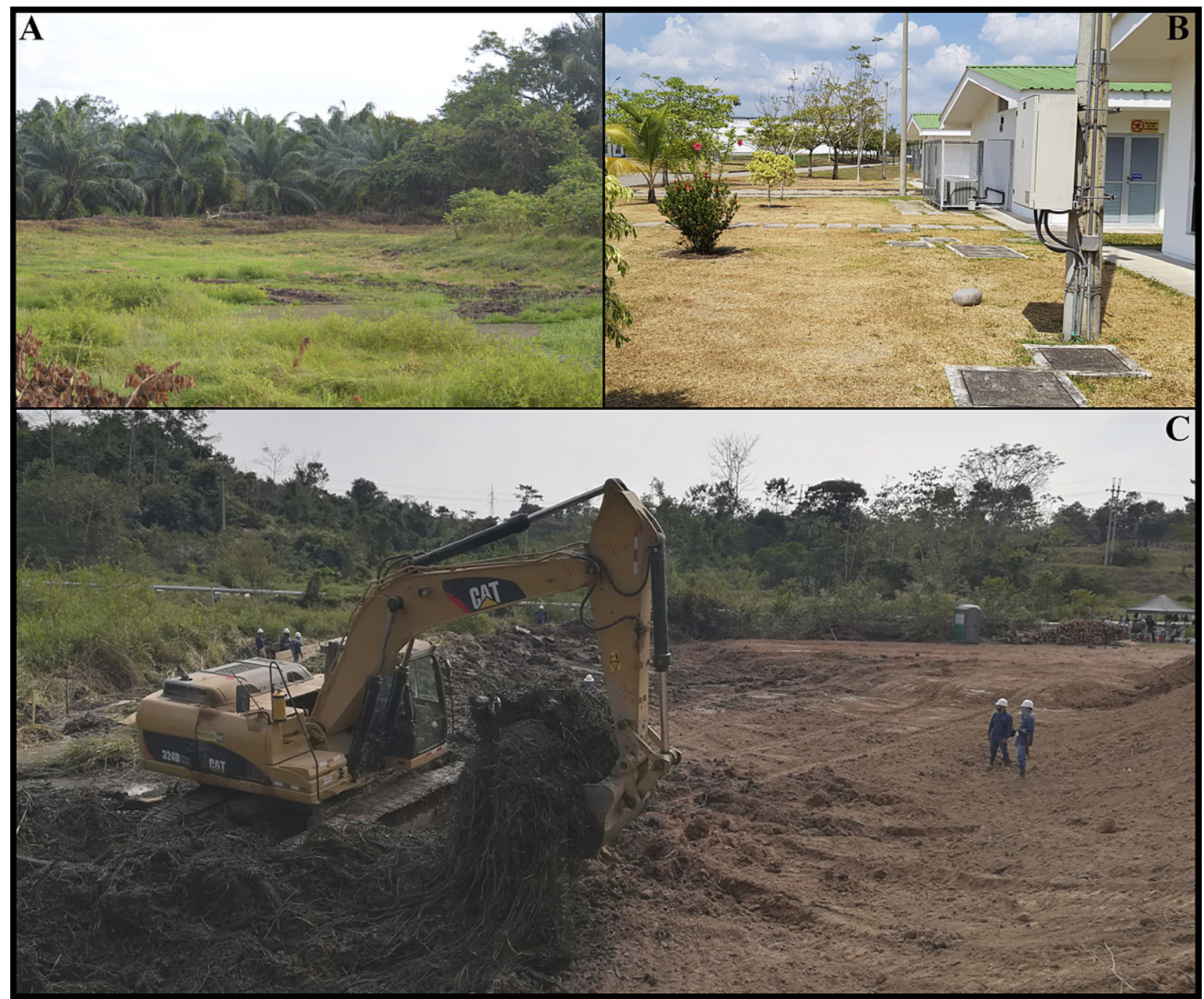

Figure 2. Habitat of Micrurus camilae. A. Palm crops and paddocks where the juvenile female was found (UIS-R-4416) La Lizama, Barrancabermeja, Santander. B. Anthropogenic site where the adult male was found (UIS-R-4416) from El Cedral, Betulia, Santander. C. Place of photographic record from Barrancabermeja, Santander. Photos: A. Diana Caballero. B. Elson Meneses-Pelayo. C. Grupo manejo de fauna Health Safety and Environment Ltd. 


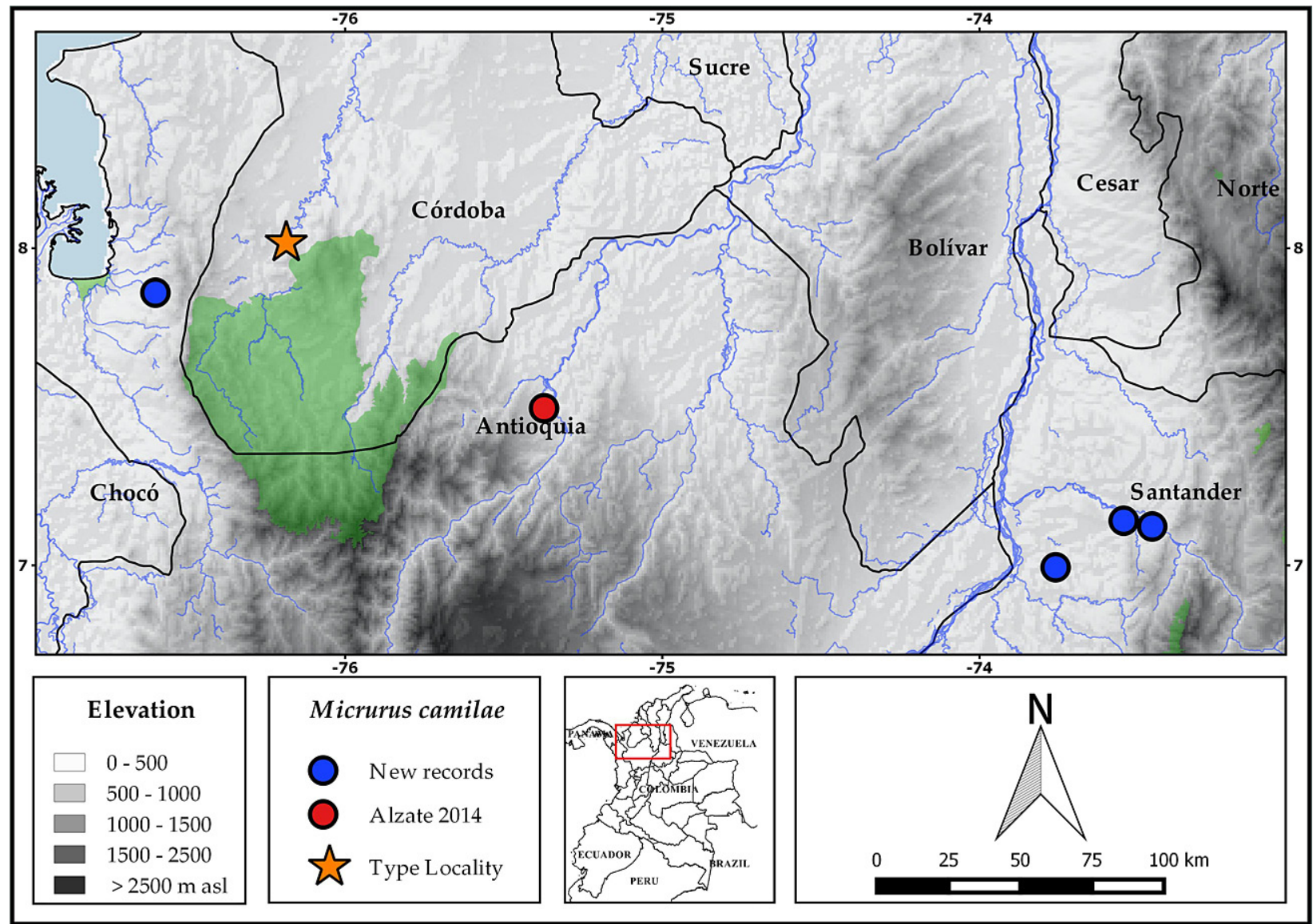

Figure 3. Current distribution of Micrurus camilae in Colombia, showing previously known (Red circles and Orange star) and new records (Blue circles). Green polygons are protected areas. Datum: WGS84.

Nueva $\left(06.9941^{\circ} \mathrm{N}, 073.7601^{\circ} \mathrm{W} ; 88 \mathrm{~m}\right.$ alt.), 2 February 2018 (Grupo manejo de fauna Health Safety and Enviroment Ltd, photographic record, Figs 1D, 2C).

Identification. The photographic record of the individual found in Apartadó (Antioquia) matches the original description in which the coloration of the snout is completely black as far as the fourth supralabial (Fig. 1C). On the other hand, the new populations found in the middle valley of the Magdalena river basin are characterized by their dorsal coloration consisting of 48 to 63 black rings; a red spot on the snout between the prefrontals and internasals; the black plate of the head only covers the first supralabial (Fig. 1B); and ventrals/subcaudals 268/40 (UIS-R-4416, male)-301/30 (UIS-R-4164, female). Different from that reported for the type series in which the black plate of the head covers up to the fourth supralabial, the red spot on the snout is absent and ventrals reported for only one male is 269 (Table 2). With this new evidence, we demonstrate that in this species there is geographic variation and sexual dimorphism in the number of ventral and black bands that was previously unreported.

\section{Discussion}

The 4 new records presented in this work expand the knowledge of the distribution of M. camilae, which now extends from Urabá region to the middle Magdalena
Valley in the ecoregion Magdalena-Urabá moist forest (sensu Olson et al. 2001; Fig. 3), with an elevational distribution between 88 (Vda. Planta Nueva, Barrancabermeja) to 176 (Vda. La Putana, Betulia) m a.s.l. With these new findings we conclude that $M$. camilae inhabits areas with high degrees of anthropogenization and fragmentation. Nonetheless, there are few records made in these areas, which could indicate a low population density. This species was classified in 2013 by the IUCN (Ines Hladki 2016) as being Data Deficient because it was known from only 3 localities and information on distribution, abundance, and trend are incomplete. because the species is known from only three localities; better information is needed on full distribution, abundance, and trend, so more data are needed. The lack of information is due to the difficulty of observing this species in the field because of its fossorial/cryptozoic habits, which may cause an underestimation of its Red List category (Bland and Böhm 2016). However, although we present new records, we still consider that more information is needed to propose a Red List category other than Data Deficient.

\section{Acknowledgements}

This work is a partial result of the master's project of EMP; the financial support was partially provided by El Grupo de Estudios en Biodiversidad. We thank Martha 
Patricia Ramírez Pinilla for revisions and suggestions to the first draft. We thank the curators of the MHN-UIS, ICN, and MHUA collections for allowing us to have access to the specimens. We are deeply grateful to Carlos Bran, Kavier González, and El Grupo de manejo de fauna of Health Safety and Enviroment Ltd for the photographic records of this work. We also thank Fernando Caceres and Rafael Mantilla for supporting with the data of one of the specimens, and Juan David Bayona Serrano for English review.

\section{Authors' Contributions}

EMP wrote the text, examined the specimens, and prepared the figures and tables; DC collected 1 of the specimens, provided data of habitat, and revised the manuscript.

\section{References}

Alzate E (2014) Geographic Distribution: Micrurus camilae. Herpetological Review 45 (2): 285-286

Bland L. M, Böhm M (2016) Overcoming data deficiency in reptiles. Biological Conservation 204: 16-22. https://doi.org/10. 1016/j.biocon.2016.05.018

Campbell J, Lamar W (2004) The Venomous Reptiles of the Western Hemisphere. Cornell University Press, Ithaca, 976 pp.

Guedes T. B, Sawaya R. J, Zizka A, Laffan S, Faurby, S, Pyron R. A, Bérnils R. S, Jansen M, Passos P, Prudente ALC, Cisneros-
Heredia, D. F, Braz H. B, Nogueira C, Antonelli A (2018) Patterns, biases and prospects in the distribution and diversity of Neotropical snakes. Global Ecology and Biogeography 27 (1): 14-21. https://doi.org/10.1111/geb.12679

Ines Hladki A, Ramírez Pinilla M, Renjifo J, Urbina N (2016) Micrurus camilae. The IUCN Red List of Threatened Species 2016: e.T44581946A44581949. https://doi.org/10.2305/iucn.uk.2016-1.rlts. t44581946a44581949.en. Accessed on: 2019-01-24.

Renjifo J, Lundberg M (2003) Una especie nuevo de serpiente coral (Elapidae, Micrurus), de la región de Urra, municipio de Tierra Alta, Córdoba, noroccidente de Colombia. Revista de la Academia Colombiana Ciencias Exactas Físicas y Naturales 27(102): 141-144.

Silva Jr NJ, Pires MG, Feitosa DT (2016) Diversidade das cobrascorais do Brasil. In: Silva Jr NJ (Ed.) As cobras corais do Brasil: biologia, taxonomia, venenos e envenenamentos. PUC Goiás, Goiânia, Brazil, 78-167.

Olson DM, Dinerstein E, Wikramanayake ED, Burgess ND, Powell GVN, Underwood EC, D'amico JA, Itoua I, Strand HE, Morrison JC, Loucks CJ, Allnutt TF, Ricketts TH, Kura Y, Lamoreux JF, Wettengel WW, Hedao P, Kassem KR (2001) Terrestrial ecoregions of the world: a new map of life on earth a new global map of terrestrial ecoregions provides an innovative tool for conserving biodiversity. BioScience 51: 933-938. https://doi.org/10.1641/00063568(2001)051[0933:teotwa]2.0.CO;2

Slowinski J, Boundy J, Lawson R (2001) The phylogenetic relationships of Asian coral snakes (Elapidae: Calliophis and Maticora) based on morphological and molecular characters. Herpetologica 57 (2): 233-245.

Uetz P, Freed P, Hošek J (Eds) The Reptile Database. http://www. reptiledatabase.org/. Accessed on: 2019-01-24. 